\title{
Study of Post-Modernism and Post-Structuralism
}

\author{
C. Tamil Selvi ${ }^{1}$, T. Thilagavathi ${ }^{2}$
}

\author{
${ }^{1}$ M.A., B.Ed., M.Phil., Nadars aras wathi College of Arts and Science, Theni, Tamil Nadu, India
}

${ }^{2}$ M.A., (English.,Lit), Nadars aras wathi College of Arts and Science, Theni, Tamil Nadu, India

\begin{abstract}
Post- Modernism was not the invention of literary critics, but literature can certainly claim to be one of the most important laboratories of postmodernism. Literary postmodernism has tended to be focused on one kind of writing, namely, narrative fiction. It seems oddly fitting that what Hutcheon says "poetics of postmodernism" should turn out to be most in evidence in its fiction. One might almost say that the move from modernism to postmodernism involves a move from poetry to fiction. Modernism had also been characterized by efforts to establish the dignity and seriousness of the novel by developing for it a kind of poetics, centered on principles of structure. This poetics operated according to the principles of a scenography.
\end{abstract}

Keywords - structuralism, modernity, post- modernity, deconstruction, Derrida arguments.

Structuralism and Structuralist Literary Theory is an intellectual movement that embraces a number of different approaches that have some basic ideas in common. The fundamental insights of Structuralism are derived from or influenced by several streams of thought.

The terms Post Modernism and Post Structuralism are partners in the same paradigm and there is bound to be some overlap between the two; some people use themeven interchangeably but it may be better to make some distinction in their use. Both Post Modernism and PostStructuralism share the view of ontological uncertainty, offer a critique of ideas regarding order and unity in language, art and subjectivity; both repudiate convictions and question wholeness, autonomy, grand theories and grand narratives; both believe that everything is fiction and that there is no realism; politics, history, sociology, psychology and even science are all fiction according to both these points of view. Post-Structuralism is more language-based whereas Post Modernism presents a vision and a way of life.

The most influential of all the Postmodernist / Post-Structuralist theories is deconstruction, propounded by Jacques Derrida. $\mathrm{He}$ is the single most influential intellectual in current philosophy and Anglo-American literary theory.

Derrida was born in 1930 in the suburbs of Algiers in a petit bourgeois Jewish family. His Jewishness, the sense of belonging to a marginal, dispossessed culture and the rabbinic tradition has had formative influences on the development of his theory. He went to france as a nineteen year old student; he studied and taught there, later dividing his time between France and the United states. Rebellion is a spontaneous activity in French society and French intellectual tradition must mock the order, State and authority; French intellectuals have a highly developed taste for attacking intellectual dwarfs. Derrida represents the French mocking tradition combined with this Jewish background. And in France he experienced a degree of rigidity and conservatis $m$ in French Universities where, in spite of all revolutions, the educational system remained unchanged; and most 'isms' rarely touched higher education-even the importance of Saussure's theory of language was not realized.

Derridean Deconstruction simply problematizes all habits of thought in any 'discipline' by demonstrating how impossible it is to draw a clear-cut line between reality and representation; this, in turn, will involve a sustained and rigorous attention to the ways in which certain notions of 'language' or 'text' have been taken for granted.

Derrida examines Rousseau's Confessions. Rousseau says, Writing is a "dangerous supplement", an addition to the natural resources of speech...a necessary evil. Derrida points out that Rousseau uses writing to debunk writing and denounces the very means by which his own ideas are set down for others to read; writing is exactly the mechanism which allows Rousseau to practice the art of concealment-to express the opposite of what he feels. Supplement is one that adds and makes the original more complete; this means that there is lack or absence of something in the original; the inadequacy or deficiency in speech can be supplement only by writing and in that case, it is not dangerous; it is not a 'necessary evil' as Rousseau says/ writes. 
Derrida argues that Saussure, like Aristotle, Plato and Rousseau takes speech as privileged because of its selfpresence; he says that it is not just speech alone that is privileged but presence is privileged over obsence. Derrida says: 'Voice becomes a metaphor of truth and authenticity...writing, on the contrary, destroys the ideal of pure self-presence.' Rousseau glorifies speech to such an extent affirming it as pure, spontaneous, authentic, original and natural that writing becomes secondary and lifeless. Privileging speech over writing is called phonocentrism; through privileging the spoken word, meaning and truth, reason and logic, the phonocentric tradition becomes really logocentric; what is actually privileged through phonocentricism is logocentricis. The logocentric tradition spans from Plato and Aristotle to Heidegger, Saussure, Levi-Strauss and Structuralism. As portrayed by Derrida, the logocentric system always assigns the origin of truth to logos to the spoken word, to the voice, reason and the Word of God.

Derrida does not deny that the use of speech comes before the use of writing in the history of language or in the learning of a language by human beings. What he argues is that the original/ true form is not necessarily the purest form. There is a distinction between historical and conceptual priority. For example, in mathematics, historically, counting was done with sticks or stones or beads but they have now been discarded for more abstract forms and formulae. We do not bring in historical priority to decide conceptual importance.

Derrida uses writing in its narrow sense as well as in its broader sense to indicate all systems that traces thinking, interior speech, or anything precedes actual speech. In the broader sense, arche-writing 'supplements perception before perception even appears to itself; so, in Derridean Deconstruction, writing, in the sense of 'traces', exists always already before perception and its presence alone is what we understand as speech. Trace is writing in general and it serves as the foundation of speech. Thus, Derrida reverses the speech/ writing hierarchy and privileges writing. After pointing out that the concept of writing cannot be reduced to graphic or inscriptional sense, Derrida proceed to deconstruct another important Saussurean statement that says: In language there are only differences without positive terms. Saussurean differences operate at two levels signifiers as well as signified. Signifiers are sound images, expressions, audible sounds in speech and visible marks in writing; signified are concepts. Both signifiers and signified a purely differential.
Derrida is not against the term signified; he puts it under erasure: Since the word is put under scrutiny it is crossed out; since it exists it remains legible but crossed. Derrida argues that 'difference' will mean presence; both entities are present.

Derrida argues: 'The essence of a rose is its nonessence; is its odour as it evaporates-the effluvium-what is thrown out-a belch, a fart, the excrements, its dissipationeffluvium designates, in general decomposing organic substances. 'The text is thus a gas'. Etymologically the text is a cloth and 'textus' is the form from which 'text' derived and it means 'woven'.

Derrida points to a suggestion by Wittgenstein. Wittgenstein remarks that one cannot say 'bububu' and mean 'If it does not rain, I shall go out for a walk'; paradoxically, Wittgenstein himself has made it possible to do that. If you are carrying a white umbrella and someone says 'I have never seen a white umbrella', you can say he has seen one. For example, an expression like 'Not now, darling' could have been said by mother to her child in front of an ice-cream parlour; the contextual meaning 'decomposes' because it can be grafted into another context.

The concept of 'relative pluralism'-the notion that 'reality' can be considered from different points of view or nayas, the realization that all is never the 'same' and even that while changing gives the impression that nothing changes, the thinking that the essential nothing is the basis for all changes, the thinking that the all judgements are relative and probable, and the faith that the essential nothing is the basis for all changes, thereby giving 'shanti'-are part of

the Indian psyche. That is why, in Indian philosophy, it is believed that one never enters the same river again by the time you come out and take another dip, the river changes and the body chemistry and the mental make-up of the one taking the bath also changes.

Structuralism and Structuralist Literary Theory is an intellectual movement that embraces a number of different approaches that have some basic ideas in common. The fundamental insights of Structuralism are derived from or influenced by several streams of thought. Modernism is a curious mixture of an abstraction and excess. The principle of abstraction is to be seen in modernism various eschewals and denials, for example in the turn away from referential objects in modernist painting and the withholding in modernist fiction of the traditional satisfactions of rounded characters, absorbing plot, and happy endings. 
Modernist reading of the novel's relation to modern life was also available from the moment of its appearance. This reading takes its led from T.S.Eliot who famously represented the mythical method of Ulysses as a way of giving an order and a meaning to the otherwise futile disorder of the world. This was extended into a full-blown modernist account of the novel in the elaborate and semiauthorized explication offered by Stuart Gilbert. It now became clear that the novel was no simple surrender to the chaotic phenomena of modern urban life, but was rather an elaborately crafted deterrence of them. Modernism contains the promise that once one grasps its algebra, even a work like Ulysses adds up to reassuringly less than the sum of its parts.

This does not represent a simple giving up of the kind of aesthetic privilege claimed by the modernist work, for postmodernism had up its sleeve another form of privilege for literary art. The early years of postmodernism in literary studies saw a strong and pervasive linguistic turn. The plenitude which postmodernist fiction would set out to match was represented not as a plenitude of things but as a plenitude of words. It is in this sense that a work such as Ulys ses can begin to be construed as a postmodernist work.

Mention the work of Beckett must signal a pause in this argument about the defining incontinence of postmodernist fiction. Beckett saw his own work as tending to the other extreme of ignorance and impotence. The work will define and maintain its integrity by an ascesis rather than an excess. His work can be said to be postmodernist in its powerful remission of the power of the artist and its suspicion of the idea of the integrity of the work but modernist in its continuing sense of the fragile residual vocation of the condition of being an artisteven if one is condemned to failure. Realist fiction was forced into dropsically distension because it felt it had to measure up to the world.

Fiction was always subsisted upon the larger ideological fiction of the reader's continuous and uninterrupted attention, or the synchronization of the narrative time of the novel and the reader's actual reading time. In a postmodern epoch this normative link between reading time and the individual subject begins to dissolve, as technological resources are developed that will perform acts of reading vicariously or at a distance recording sorting and sorting information for acts of reading at different times which no longer have an obvious or regular relationship with the reading times of individual readers. In containing to make orders of magnitude unignorable, postmodernist fiction seems to show that we cannot entirely do without the old systems of weights and measures, as we attempt to take readings of a world that has gone off the scale.

\section{REFERENCES}

[1] Connor, Steven; Post Modernism Published by The Press Syndicate Of The University Of Cambridge.

[2] Varghese, John \& Krishnaswamy, k Contemporary Literary Theory A Students Companion Published by Rajiv Beri for Macmillan India Ltd. 